Editorial

\title{
Introducing the Study of Nordic Cooperation
}

\author{
Anne Elizabeth Stie ${ }^{1, *}$ and Jarle Trondal ${ }^{1,2}$ \\ ${ }^{1}$ Department of Political Science and Management, University of Agder, 4604 Kristiansand, Norway; \\ E-Mails: anne.e.stie@uia.no (A.E.S.), jarle.trondal@uia.no (J.T.) \\ ${ }^{2}$ ARENA Centre for European Studies, University of Oslo, 0318 Oslo, Norway \\ * Corresponding author
}

Submitted: 6 October 2020 | Published: 3 November 2020

\begin{abstract}
To rediscover Nordic cooperation this article develops a 'conceptual grammar' that provides general theoretical 'images' of cooperation that are systematically applied. Being supplementary analytical constructs, moreover, these images capture great variety and differentiation in Nordic cooperation. Next, this article provides a review of two sets of literature that are of particular relevance to this thematic issue. The first is a broader literature on European integration. The second is studies of Nordic cooperation. The article closes with an overview of the contributions to this thematic issue.
\end{abstract}

\section{Keywords}

differentiation; disintegration; integration; Nordic cooperation; Nordic Council; Nordic Council of Ministers

\section{Issue}

This editorial is part of the issue "Rediscovering Nordic Cooperation" edited by Anne Elizabeth Stie (University of Agder, Norway) and Jarle Trondal (University of Agder, Norway/ARENA University of Oslo, Norway).

(C) 2020 by the authors; licensee Cogitatio (Lisbon, Portugal). This article is licensed under a Creative Commons Attribution 4.0 International License (CC BY).

\section{Introduction}

Situated in the North-Western corner of Europe, the five countries-Sweden, Denmark, Norway, Finland and Iceland as well the autonomous regions of Faroe Islands, Greenland and Åland Islands-make up 'Norden' or the Nordic countries. Yet, is 'Norden' more than a geographical area, more than a shared territorial landscape, or are Nordic states able to govern together? Do Nordic states share ways of cooperating through common politico-administrative institutions, networks and traditions? Is Nordic cooperation characterised by shared and pooled sovereignty and resources towards one 'common order,' or is it better portrayed as divergent and poorly coordinated set of institutions and resources (Trondal, 2020)? To what extent is Nordic cooperation a bi-product of and profoundly influenced by exogenous factors such as the European Union (EU), and to what extent is it shaped endogenously by distinct Nordic politico-administrative institutions and traditions (Olsen \& Sverdrup, 1998)? This thematic issue aims to rediscover Nordic cooperation as a laboratory for analysis as well as a region of politico-administrative cooperation. More precisely, we examine to what extent Nordic cooperation represents an integrated and independent 'common political order,' and the extent to which it represents an area of politico-administrative differentiation. Although 'Norden' is often recognized as sharing a common political, economic and administrative model with a fairly cohesive cultural identification among citizens, trust-based governance and a strong welfarestate tradition, Nordic political cooperation has largely remained secondary to both national and EU-level politics. Similarly, Nordic political science has focused relatively more on the politics of the Nordic states and the EU than on Nordic cooperation (Knutsen, 2017). Despite being largely pictured as withering (Olsen \& Sverdrup, 1998), observations presented in this thematic issue suggests that Nordic cooperation is vibrant, yet partly overlapping with other regional politico-administrative networks, and also that it is characterised by politicoadministrative differentiation. 
Over the last decade, Europe has been hit by multiple crises that have tested the post-Cold War political order based on institutional multilateralism, rule of law and policy compromises (Dinan, Nugent, \& Paterson, 2017; Graziano \& Halpern, 2016; Riddervold, Trondal, \& Newsome, 2020): the financial and migration crises, Brexit, democratic backsliding, climate change, Russia's annexation of Crimea, cyber-security threats, uncertainties about multilateralism and the future role of the US, the rise of China, and lately, the unpredictable unfolding and consequences of the Covid-19 pandemic. With evermore turbulence in world affairs, there is a call for understanding the conditions for sustained political order (Ansell, Trondal, \& Ogard, 2016; Boin, t' Hart, Stern, \& Sundelius, 2005; Fukuyama, 2016; Olsen, 2007). The significance of political order is often taken for granted during historical periods of stability. During periods of political unrest, however, existing political arrangements easily become subject to contestation and request for reform (Ansell \& Trondal, 2017). Against this background, Olsen and Sverdrup (1998) observed a withering of Nordic cooperation-it was pictured as secondary to an ever more integrated EU. Reasons for this was different forms of affiliation to the EU among the Nordic countries (Olsen \& Sverdrup, 1998), weak institutions to support Nordic cooperation (Sundelius \& Wiklund, 1979), as well as the dynamics of European integration. For historical reasons too, the Nordic states have been sceptical of pooling sovereignty to the Nordic level and have also been tortoises in European integration. Previous studies have thus pictured Nordic countries as 'reluctant Europeans' (Miljan, 1977), 'reluctant Nordics' (Arter, 2008), 'awkward partners' (Stegmann McCallion \& Brianson, 2018) or the 'other European Community' (Turner \& Nordquist, 1982).

This thematic issue paints a picture of differentiated Nordic administrative cooperation between central administrative institutions. It showcases how Nordic cooperation is vibrant and largely facilitated by agencyto-agency cooperation and only weakly coupled to the Nordic Council (NC) and the Nordic Council of Ministers (NCM). Nordic-level institutions arguably do not possess requisite administrative capacities to co-opt national administrative institutions (Trondal, 2020). Moreover, Strang (2016), Hyde-Price (2018), Olesen and Strang (2016) and Kettunen, Lundberg, Österberg, and Petersen (2016) also observe that there is a 'Nordic renaissance' attached to the praise of the Nordic (welfare) model as well as Nordic collaboration in security and defence policy (see also Wæver, 1992). On the other hand, cooperation in the traditional formats of the NC and NCM in policy areas such as social and welfare policy, law, arts and culture, remain weak. Nordic cooperation thus faces dilemmas of integration, fragmentation and differentiation. It is therefore timely to take stock of Nordic cooperation.

To aid the discussion, three conceptual images are developed as analytical guides: Image 1 suggests that
Nordic cooperation is characterized as one common political order; Image 2 suggests that Nordic cooperation is largely absent, and that politics of the region is largely driven by non-cooperating states; Image 3 finally advocates that Nordic cooperation is characterized by differentiated integration in which different parts of the region, and different institutions therein, cooperate to different extents, at different times and at different speeds in different policy domains.

These conceptual images differ on the extent to which politico-administrative orders are 'common' (Trondal, 2020). However, an 'order' does not suggest political institutions that are perfectly integrated, coordinated and impeccably independent. They are often imperfectly so. The notion of common political order suggests a fairly independent, integrated and influential set of institutions that allocate 'authority, power, information, responsibility, and accountability' (J. P. Olsen, 2016 , p. 3). A common political order, however, is conceptually different from processes of integration (see Riddervold et al., 2020). The meaning of the term 'integration' varies across theoretical perspectives in the literature (Wiener, Börzel, \& Risse, 2019). Overall, we choose a general definition of integration suggested by James G. March (1999, p. 134) who sees integration as the imagination of "a world consisting of a set of parts. At the least, integration is gauged by some measure of the density, intensity, and character of relations among the elements of that set." Subsequently, he suggests three parameters for integration: consistency among the parts, interdependence among the parts, and structural connectedness among the parts. On this basis, disintegration would imply a lower degree of density and intensity of the consistency, interdependence and structural connectedness among these parts.

\section{Conceptual Images of Nordic Cooperation}

This section develops a 'conceptual grammar' that provides three fairly general images of cooperation. Being supplementary analytical constructs, these images capture variation in Nordic cooperation. Each article in this thematic issue moreover offers causal mechanisms to explain such variation.

First, Image 1 proposes that Nordic cooperation is characterised by deep integration into one common political order. This scenario suggests some kind of deep integration of states, institutions and policies. The empirical test would be political institutions at the Nordic levelnotably NC and NCM-that are integrated, coordinated and independent of the politics of member-states. Generally, crises tend to trigger integration of states and/or administrative bodies to address common challenges (Riddervold et al., 2020). Crisis may entail a fundamental questioning of pre-existing governance arrangements and 'long-cherished beliefs' in existing institutional systems (Lodge \& Wegrich, 2012). Crisis may produce critical junctures that generate 'windows of opportuni- 
ty' for significant policy change (Kingdon, 1984) and novel organizational solutions (Jones \& Baumgartner, 2005). Crisis may thus spur the emergence of entirely new policies or institutional arrangements. Recent examples include the rise of EU financial surveillance agencies and the structuring of an EU banking union in the aftermath of the financial crisis, the emergent European energy union in the aftermath of energy and climate crises (Trondal \& Bauer, 2017). An organization theory approach might account for deep administrative integration across states. Integrating central administrations of states are first conditioned by vertical specialization of administrative bodies in general, and the creation of agencies subordinated to ministerial departments in particular. Hence, loose coupling of organizations in general increases the sum of organisational sub-units that might subsequently interact. Decentralised agencies are shown to govern on arm's length distance from political control and therefore possess requisite administrative autonomy to collaborate with agencies in other government systems-and thus 'go Nordic' (Egeberg \& Trondal, 2018). Secondly, these horizontal administrative networks are likely to be verticalized and absorbed by international bureaucracies if the latter possess requisite administrative capacities to pull administrative bodies into its own orbit.

By contrast, Image 2 suggests that Nordic cooperation is weak, disintegrated, hollowed-out and characterised by separate policy agendas driven by noncooperating states and administrative bodies (Olsen \& Sverdrup, 1998). The empirical test would be political institutions at Nordic level-notably NC and NCM-that are poorly coordinated and largely dependent on the politics of member-states. Following an organisational theory approach, weak Nordic cooperation might result from how Nordic cooperation is (dis)organised (Egeberg \& Trondal, 2018). Deep forms of association among states would require requisite joint organisational platforms to develop and survive. By contrast, a lack of common politico-administrative institutions among Nordic states-notably a weak NC and NCM-would lead to weak integration of politics and policies.

Finally, in line with contemporary studies of differentiation in EU studies, Image 3 suggests that Nordic cooperation is characterised by differentiated integration in which different parts of the region, and different institutions therein, integrate to different extents, at different times, and at different speeds in different policy domains (Leruth, Gänzle, \& Trondal, 2019). This conceptual image is compatible with a historicalinstitutional approach, in which Nordic cooperation muddle through via processes of institutional and policy path-dependencies: Policy processes are thus contingent on and locked in by pre-existing institutional formats, and therefore profoundly stable, sustainable and robust (Pierson, 2000, 2004). Institutions create elements of robustness, and concepts such as historical inefficiency and path-dependence suggest that the match between environments and institutional solutions is not automat- ic and precise (March \& Olsen, 1998). Faced with crises, new governing arrangements are thus likely to be extrapolated from and mediated by pre-established institutional frameworks (Skowronek, 1982). Differentiated Nordic cooperation is fashioned by the diverse set of organisational solutions among Nordic administrative bodies, interest groups, regional administrations, and so on (Jacobsson, Lægreid, \& Pedersen, 2004).

\section{European Integration and Nordic Cooperation: Review of the Literature}

We see two sets of literature that are of particular relevance to this thematic issue. The first is a broader literature on European integration and the second is studies of Nordic cooperation.

\subsection{Studies in European Integration}

Contemporary advances in EU studies have occurred in the aftermath of EU polycrisis that was triggered with outbreak of the financial crisis in 2008. Multiple crises have led scholars to ask if the EU integration process is brought to a halt or experiences disintegration, or if forms of differentiation is emergent. Crisis, disintegration and differentiation have faced 'grand-theories' of European integration such as neofunctionalism and intergovernmentalism with conceptual and explanatory problems, while mid-range theories such as neo-institutionalisms have fared comparatively better. However, most discussions of theoretical rehabilitation in the literature has privileged grand theories (e.g., Hooghe \& Marks, 2009; Schimmelfennig \& Winzen, 2019). One reason might be that big theoretical ideas may explain general trends more adequately than mid-range theories. One comprehensive attempt to 'explain' crisis and European disintegration is Vollaard (2014), written in the context of the Euro-crisis. Vollaard suggests that studies of differentiated (dis)integration "only explain why some member-states do not join all integrative steps, and not whether the EU could become less integrated" (Vollaard, 2014, p. 1143). Following Vollaard (2018), integration is seen as multifaceted processes that co-exist with disintegrative ones (see below). Focusing, inter alia, on the so-called 'migration crisis,' Webber (2019) further expanded on a second comprehensive theoretical contribution-post-functionalismarguing that Hooghe and Marks' (2019) approach is best equipped to understand the consequences of the crisis on European integration, as post-functionalism argues that " $[\mathrm{m}]$ ass politicization and the growth of identity politics are likely to create 'downward pressure on the level and scope of integration"' (Hooghe \& Marks as cited in Webber, 2019, p. 8). Recent studies provide rich empirical probes of how the EU has responded to crisis, whilst some few studies also aim to theoretically explain mechanisms of how the EU tackle crisis, e.g., through disintegration (Vollaard, 2018), or concep- 
tually assess effects of crisis on the European political order, for example by pushing the EU towards differentiation and segmentation (e.g., Bátora \& Fossum, 2019). Both Vollaard (2018) and Bátora and Fossum (2019) suggests that the EU has muddled through crises, either by member-states balancing different choices of exit, voice and loyalty (Vollaard, 2018), or institutionally through lock-in mechanisms influenced by pre-existing segmented institutional arrangements (Bátora \& Fossum, 2019). Thus, contemporary theorizing of (dis)integration and differentiation in Europe combines explanations based on collective actors' cost-benefit calculations-such as promotion of equality of opportunity among EU members (Jones, 2018)-and institutionalist explanations focusing on how crises are channelled through and mediated by pre-existing institutional frames and resources (e.g., Bátora \& Fossum, 2019).

Brexit revoked differentiated integration as a promising focus in EU studies. Common to this literature is that crisis is seen as a catalyst both of increased European differentiation and increased scholarly attention to the phenomenon. Following Bátora and Fossum (2019), a symposium in Journal of Common Market Studies by Leruth et al. (2019) argued that differentiation is a persistent and embedded phenomenon in the EU. Differentiation is furthermore driven by mechanisms of supply and demand: Those on the demand side consist of national governments that do not wish to follow the integrationist path taken by the inner core of the EU, while the supply side consists of pro-integrationist governments that accept the demands to move away from uniformity. Differentiation, arguably, covers processes under which a member-state withdraws from participation in the process of European integration (full exit; Leruth et al., 2019), or component parts of member-states withdraws (partial exit), leading to processes of differentiated disintegration (Vollaard, 2018, p. 233). Similar tendencies are likely in sub-regional cooperation, such as Nordic cooperation.

Vollaard (2018) argues that differentiated disintegration requires original conceptualisations and theorybuilding. Arguably, mid-range theories would allow for more careful causal probes as well as the possibility of explaining the details of events more adequately than grand theories. Mid-range theories such as institutional theories have been generally used to explain how exogenous chocks are adopted and biased endogenously by rules and routines (March \& Olsen, 1989). Applied to understand how the EU adapts to crisis, institutional segmentation of the EU has similarly been shown to foster differentiated crisis sensitivity and crisis management within different policy areas and institutions. Consequently, crisis in one policy area does not easily spill over to other policy areas, thus not reverberating across the entire system. Put generally, 'bad' solutions may be implemented in parts of organizations or political orders without 'ruining it all' (Ansell \& Trondal, 2017). Similar ideas led Genschel and Jachtenfuchs (2018) to argue that processes of (dis)integration may unfold differently in different policy areas, notably in policies of core-state powers-through capacity-building-and policies of market integration-through (re-)regulation. Similarly, Falkner (2016) argued in a special issue of Journal of European Integration that crisis pressure has been unequally distributed between nine policy areas and the effects have been mediated by EU's decisionmaking 'modes' and layered on top of existing elements. Falkner $(2016$, p. 229) shows that no policy area experienced integration 'failures' and a re-nationalisation of competences and capacities. In short, poly-crisis contributed to 'an even greater role to the EU,' partly due to spill-over by stealth (Mény, 2014). The latter observation led Mény (2014) to argue that crisis has contributed to a possible 'federalism of executives,' with a shift of power towards executive institutions, albeit segmented across different policy sub-systems (Bátora \& Fossum, 2019).

The above discussion thus suggests a call for eclecticism in theory and methods as well as for mid-range theorizing. One such contribution is Leruth et al. (2019), exploring differentiated disintegration from multiple theoretical angles, focusing on how this process affected different policy areas, norms and institutions of the EU. However, differentiation is not merely understood as yet another form of or response to crisis. The process of European integration is abundant with examples of fundamental crises, such as the ones triggered by the failure of the European Defence Community in 1954, the empty chair crisis of 1965-1966 or the 'euro-sclerosis' of 1970 , to name but three. Yet, the full disintegration of the Union has never happened, and according to Vollaard $(2018$, p. 259$)$ is not likely to happen any time soon.

\subsection{Studies in Nordic Cooperation}

The end of the Cold War triggered substantial soulsearching in Nordic region (Olesen \& Strang, 2016; Strang, 2016). When the Nordics ended up choosing different forms of affiliation to the EU-Sweden and Finland joining Denmark in the EU, and Norway and Iceland remaining as members of the European Economic Area-observers assumed that Nordic cooperation would erode, reducing it to a less attractive sub-arena for the then newly accessed EU members (Olsen \& Sverdrup, 1998). However, whereas one strand of literature viewed European integration as a threat to further Nordic cooperation (and to national sovereignty), the other was pragmatic and saw possibilities for differentiated Nordic cooperation inside the EU. This section discusses two areas of scholarship on Nordic cooperation: Transnational administration and networks and security and defence cooperation.

\subsubsection{Transnational Administration and Networks}

Whereas European integration has been pursued largely by European elites in a top-down way, Nordic coop- 
eration has had a distinctive bottom-up dimension characterised by informal networking and coordination among national administrations and stakeholders (Andrén, 1967; Götz \& Haggrén, 2009; Olsen \& Sverdrup, 1998; Strang, 2016, p. 8; Sundelius \& Wiklund, 1979). This involves informal collaboration among national bureaucrats to coordinate policy positions, seeking inspiration and learning, exchange of contacts, discussing EU regulations, providing help in single cases, and pooling resources and competences (Kettunen et al., 2016; Lægreid \& Rykkja, 2020; Olsen \& Sverdrup, 1998; Sundelius \& Wiklund, 1979). This 'transnational bureaucracy' (Sundelius \& Wiklund, 1979) of inter-connected ministries and agencies is pictured as part of a development towards a common Nordic administrative space (Lægreid \& Rykkja, 2020). However, unlike EU institutions and in particular the European Commission's ability to set the policy agenda for member governments (cf. Bauer \& Trondal, 2015; Egeberg \& Trondal, 2018), the inter-parliamentary NC and the intergovernmental NCM are much less able to mobilise a common Nordic agenda and to enforce implementation of it. Instead, Nordic cooperation mainly takes place in loosely coupled administrative networks, which sometimes run via and often outside the NC and the NCM. Another characteristic of these networks is that they have primarily emerged and been maintained sector-wise. This has made inter-sectoral Nordic coordination challenging, rendering package-deals across policy domains few. On the other hand, this might also make Nordic cooperation more resilient; if cooperation in one policy domain falters or breaks down, this does not easily lead to breakdown in other policy sectors.

The surge of European integration has oriented Nordic cooperation towards the EU and challenged attention towards Nordic integration (Etzold, 2020; Olesen \& Strang, 2016; cf. Strang, 2016). It has become difficult for Nordic governments to discuss Nordic cooperation outside the context of European institutions. Nordic administrative networks are therefore overly EU-focused. Olsen and Sverdrup (1998) suggested that European integration would hollow out Nordic cooperation. Not only would EU membership be time-consuming and resource demanding by moving attention away from the Nordic agenda and weaken attentiveness towards Nordic institutions and cooperation. Moreover, the EU might also be equally or more attractive to governments. This thematic issue, however, suggests that Nordic administrative cooperation in sectoral, transnational networks are 'alive and kicking' driven by agencyto-agency networks (Lægreid \& Rykkja, 2020). Such networks are partly Europeanised by being tightly coupled to EU institutions and policy processes (i.e., in the Commission and EU agencies). Nordic administration cooperation is thus as a gateway to EU arenas, and those involved would experience agenda-overlap. For instance, the Norwegian Water Resources and Energy Directorate operates both in Nordic and EU agency net- works but contact with the Commission are primarily channelled via EU agencies and Nordic associations (Andersen, 2016). A recent study of the Norwegian Directorate for Civil Protection shows that there is significant overlap between the Nordic and EU administrative networks (A. L. Olsen, 2016).

These studies suggest that national regulatory agencies 'go Nordic' but 'EU too' to discuss common challenges and EU regulations, and they coordinate common positions at the Nordic level prior to EU meetings. Exchange of experiences and information contributes to policy coordination among Nordic agencies, but also to a division of labour among them. Similarly, Nordic cooperation are observed between statistical agencies in the Nordic countries (Teigen \& Trondal, 2015), Nordic water systems and energy agencies (Andersen, 2016), civil protection agencies (A. L. Olsen, 2016) and agencies in the pharmaceutical sector (Vestlund, 2015). Similarly, the Financial Supervisory Agency of Norway and the Norwegian Directorate of Health use Nordic cooperation as a gateway to the EU (Isaksen, 2012; Søetorp, 2012). Nordic cooperation is seen as useful, as a collegial arena for learning, coordination and early warning on forthcoming EU directives. Nordic and EU decision-making processes consequently overlap, largely caused by the dynamic regulatory activity of the EU.

Most contributions to this thematic issue observe that Nordic cooperation is differentiated and (unsurprisingly) neither sufficiently deep nor influential to render the Nordic region an independent political order. However, unlike Olsen and Sverdrup's (1998) observation of Nordic disintegration two decades ago, Nordic cooperation has seemingly not altogether decreased even if the status and influence of Nordic-level institutions is modest (Olesen \& Strang, 2016; cf. Strang, 2016). Whereas the NC and the NCM at their best "contributed to a Nordification of political discourses and to the promotion of inter-Nordic exchange of ideas among governments and civil servants" (Olesen \& Strang, 2016, p. 29), they have limited policy scope (mainly covering social and welfare issues, culture and art), formal authority and administrative capacities. However, this does not leave Nordic cooperation obsolete. Rather, it is (still) channelled through informal and flexible administrative platforms, such as transnational administrative networks among Nordic administrative bodies (cf. Lægreid \& Rykkja, 2020; Time \& Veggeland, 2020). Moreover, Nordic EU member-states also cooperate in EU policy making processes. For instance, Schulz and Henökl (2020) show that in EU financial and budgetary policy, Nordic member-states have successfully collaborated in coalition-building in the 'Hanseatic League' and the 'Frugal Four.' However, these network arrangements are flexible, informal, issue-specific and non-committing in nature and without involving Nordic-level institutions. Nordic cooperation thus remains politically and de jure intergovernmental and largely building on administrative networks. 


\subsubsection{Security and Defence Cooperation}

Notwithstanding Nordic cooperation happening mostly outside the common institutional framework of the NC and NCM, we are witnessing renewed push for Nordic cooperation in certain policy domains, such in security and defence (e.g., Forsberg, 2013; Hyde-Price, 2018, p. 436; Olesen \& Strang, 2016; Strang, 2016). During the Cold War, security and defence policy was not a viable candidate for Nordic cooperation. After unsuccessful attempt to launch a Scandinavian Defence Union in 1948-1949, Denmark, Norway and Iceland joined NATO, Sweden remained unaligned, and Finland balanced its relationship with the USSR through the Agreement of Friendship, Cooperation and Mutual Assistance. To retain this delicate Nordic balance, security and defence policy never entered the agendas of the NC and NCM. However, even as the end of the Cold War invited Nordic states to redefine their international alignments, divergent historical experiences in security and defence policy has made joint efforts to integrate this policy domain at Nordic level difficult. Shared initiatives have therefore been addressed outside the institutional framework of the NC and NCM (Bengtsson, 2020). Even if some joint progress has been achieved, deep institutional or policy integration in security and defence is hampered by the Nordic states' past foreign policy choices and identities, especially their different relations to the US and NATO, but also their different affiliations with the EU. Institutional and policy 'stickiness' in security and defence is confirmed by Haugevik and Sending (2020) who show how the Nordic states 'choose' to commit to old strategies where they have foreign policy instruments and resources.

\section{Overview of the Thematic Issue}

Tobias Etzold (2020) provides an overview of the aspiration for policy relevance of the NCM. This institution underwent an incremental process of change and some modest transformation since the 1990s. However, there has never been a major overhaul of structures and contents owing to considerable inertia. The most recent modernisation process aiming at more political relevance and flexibility has been ambitious but whether it has been a success has remained unclear so far. Weaknesses and limits of the cooperation in the NCM are obvious, i.e., no majority voting or 'opting-out' system, a lack in supranational structures and policies and no common immigration, foreign, security and EU policies. Nonetheless, the organisation has at least some relevance and meaning for the Nordic countries and the potential to promote and facilitate cooperation in policy areas in which common interests exist such as environment, climate, research and social affairs. Therefore, rather than constituting a common political order of its own, Nordic cooperation as it is conducted within the $\mathrm{NCM}$ is best characterised by differentiated integration, fostering cooperation and coordination of policies where possible and desired.

Per Lægreid and Lise Rykkja (2020) studies Nordic administrative cooperation on policy design and administrative reform measures. Their article examines whether Nordic administrative collaboration is still 'alive and kicking,' or whether it has been marginalised by increased integration into Europe and strong international reform trajectories. They analyse the scope and intensity of Nordic administrative collaboration based on the perceptions of civil servants in the Norwegian central government. Also, the implications of Nordic collaboration for policy design and reform measures are addressed. The main observation is that Nordic administrative collaboration can best be described as differentiated integration. The broad scope of Nordic administrative collaboration varies significantly with internal structural features. Nordic collaboration is seen to have an effect on policy design more than on specific administrative reform means and measures, but structural features matter too.

Next, Kjerstin Kjøndal (2020) offers a study on Nordic cooperation within the nuclear safety sector. Despite low level of Nordic cooperation as a consequence of EU integration, this article argues that longstanding Nordic networks grounded in professions and state administration may prove to be robust toward external changes. She analyses Nordic cooperation between the national radiation protection and nuclear safety authorities in Iceland, Denmark, Norway, Sweden and Finland by mapping behavioural perceptions of agency staff. The study finds that Nordic cooperation is differentiated between the highly integrated field of radiation protection and emergency preparedness and characterised by low level of integrated in nuclear security and safeguards. To account for variation the article probes the influence of path-dependency and policy portfolio.

Sarah Kilpeläinen (2020) examines Nordic cooperation in renewable electricity policy in Finland and Sweden. The article evaluates the policy mixes in Finland and Sweden with a special focus on bottlenecks and development needs and explore the viewpoints of stakeholders from these two countries regarding potential and bottlenecks for developing Nordic energy cooperation. The study thus examines renewable electricity policy development in Finland and Sweden against the backdrop of facilitating and accelerating the Nordic energy transition.

Martin Time and Frode Veggeland (2020) examine the management of antimicrobial resistance (AMR) in the Nordic countries. Guided by assumptions derived from institutional theory, the study compares how AMR has affected the administrative systems and cooperative framework within and between the Nordic countries. The article observes that adapting to AMR management in the Nordics is only to a limited extent affected by international influence. Compatible with the image of differentiated integration, adaptation takes place through incremental change within existing structures for disease 
prevention and control and follows traditional ways of organising political and administrative systems.

Reini Schrama, Dorte Sindbjerg Martinsen, and Ellen Mastenbroek (2020) offer an analysis of the Nordic dimension of European administrative networks. Integration and policy-making in the EU are often assumed to challenge Nordic cooperation as a separate 'common order.' Increasing interdependencies in the EU have forced EU member states to collaborate and share sovereignty in an increasing number of policy areas. This article studies the co-existence of Nordic cooperation with European integration, by taking a network approach. It analyses the extent to which Nordic members of European administrative networks 'go Nordic' to solve problems or exchange advice, information and best practices. The data suggests that Nordic cooperation in the EU and EEA is best characterised by differentiated integration. Nordic states tend to form a separate community for problem solving and exchanging best practices, advice and information in health and social policy networks, but less so a network related to the internal market.

Next, Daniel Schulz and Thomas Henökl (2020) examine new alliances in Europe and ask if the New Hanseatic League revive Nordic political cooperation. As Brexit removes the Nordic countries' most powerful ally from the EU, the article asks what this imply for their approach to European affairs? The literature on small states within the EU suggests that they can counterbalance limited bargaining capacities by entering two types of alliances: strategic partnerships with bigger states such as the UK, and institutionalised cooperation on a regional basis. Against this backdrop, the article analyses whether the Brexit referendum has revitalised Nordic cooperation by significantly raising the costs of non-cooperation for Nordic governments. The article analyses Nordic strategies of coalition building on EU financial and budgetary policy, specifically looking at attempts to reform Europe's Economic and Monetary Union and proposals to strengthen the EU's fiscal powers. The study finds that Nordic governments have successfully collaborated on these issues in the context of new alliances such as the 'New Hanseatic League' or the 'Frugal Four.' Yet, their coalition-building strategies rely on relatively loose and issue-specific alliances rather than an institutionalisation of Nordic political cooperation, implying that this revival of Nordic political cooperation hardly involves the institutions of 'official' Nordic cooperation. The article argues that this reflects lasting differences among the Nordics' approach to the EU as well as electorates' scepticism about supranational institutionbuilding, implying that 'reluctant Europeans' are often also 'reluctant Scandinavians.'

Benjamin Leruth, Jarle Trondal, and Stefan Gänzle (2020) compare party positions on differentiated European integration in the Nordic countries. The article argues that the Nordic countries constitute a viable laboratory for the study of differentiated European
Integration. Even though Denmark, Finland, Iceland, Norway and Sweden share some common characteristics, they have opted for different relationships with the EU. Essentially, this variation is reflected in Nordic parties' positioning vis-à-vis European integration in general and differentiation of European integration in particular. The study examines similarities and differences between parties belonging to the same ideological family, and the extent of transnational party cooperation in the Nordic countries. Broadly speaking, party families can be distinguished along traditional (e.g., agrarian, Christian democratic, conservative and social democratic) and modern (e.g., socialist left, green and populist radical right) ideological orientations. Compatible with the image of differentiated integration, the study shows that although institutionalised party cooperation mostly reflects divisions between party families, such institutionalisation does not include a common vision for European integration. It is concluded that the low level of partisan Nordic integration is primarily caused by domestic-level factors, such as intra-party divisions, government participation and public opinion.

Rikard Bengtsson (2020) offers a study of Nordic security and defence cooperation and policy differentiation. A decade ago, Nordic cooperation on security and defence matters gained momentum, after having been largely absent from the map of Nordic cooperation during the Cold War. This article analyses developments along three dimensions of Nordic cooperation-military defence, civil security and political cooperation. Three observations are highlighted: First, the three dimensions are intimately related against the background of a common Nordic conceptualisation of security; second, there is simultaneously variation in significant respects (such as driving forces, scope, and degree of institutionalisation); and third, Nordic security and defence cooperation has developed in the context of European and transatlantic security dynamics and cooperation.

Following the previous article, Kristin Haugevik and Ole Jacob Sending (2020) offer a study of differentiation in the foreign policy repertoires of the Nordic countries. Nordic government representatives frequently broadcast their ambition to do more together on the international stage. They also share a number of basic traits as foreign policy actors, including a steadfast and explicit commitment to the safeguarding of the 'rules-based international order.' Why, then, do we not see more organised Nordic foreign policy collaborationfor example in the form of a joint 'grand strategy' on core foreign policy issues, in relation to great powers and in international organisations? The study draws on Charles Tilly's concept of repertoires to highlight how the bundles of policy instruments that states develop over time takes on an identity-defining quality. The Nordics states, the article observes, have invested in and become attached to their foreign policy choices and differences. Reflecting policy differentiation, this observation makes it unlikely that we will see a 'common order' among 
the Nordic states in the foreign policy domain in the near future.

The thematic issue closes with a conceptual epilogue by Jarle Trondal (2020) on public administration and the study of political order. The article makes a plea for public administration scholarship in the study of political order. The article outlines a conceptual framework on political order and offers empirical illustrations on Nordic cooperation. Political order consists, it is argued, of a relatively stable arrangement of institutions that are fairly formalised and institutionalised. A common political order, moreover, entails that relevant institutions: (i) are fairly independent of pre-existing institutions; (ii) are relatively integrated and internally cohesive; and (iii) are reasonably able to influence governance processes within other institutions. Reflecting empirical observations made in this thematic issue, the article suggests that Nordic-level institutions are less able to act integrated and independently of member-state governments as well as wielding significant influence on policy processes within member-state governments and administrations.

\section{Acknowledgments}

The authors acknowledge helpful responses from contributors to the thematic issue.

\section{Conflict of Interests}

The authors declare no conflict of interests.

\section{References}

Andersen, S. R. (2016). En europeisk administrasjon over flere nivåer? En studie av Norges vassdrags- og energidirektorats arbeid med EU-regelverk [An European administration across several levels? A study of the Norwegian Water Resources and Energy Directorate] (Unpublished Master dissertation). University of Oslo, Oslo, Norway.

Andrén, N. (1967). Nordic integration. Cooperation and Conflict, 2(1), 1-25.

Ansell, C., \& Trondal, J. (2017). Governing turbulence: An organizational-institutional agenda. Perspectives on Public Management and Governance, 1(1), 43-57.

Ansell, C., Trondal, J., \& Ogard, M. (Eds.). (2016). Governance in turbulent times. Oxford: Oxford University Press.

Arter, D. (2008). Scandinavian politics today (2nd ed.). Manchester: Manchester University Press.

Bátora, J., \& Fossum, J. E. (Eds.). (2019). Towards a segmented European political order. London: Routledge.

Bauer, M. W., \& Trondal, J. (Eds.). (2015). The Palgrave handbook of the European administrative system. Houndmills: Palgrave Macmillan.

Bengtsson, R. (2020). Nordic security and defence cooperation: Differentiated integration in uncertain times. Politics and Governance, 8(4), 100-109.
Boin, A., t' Hart, P., Stern, E., \& Sundelius, B. (2005). The politics of crisis management. Cambridge: Cambridge University Press.

Dinan, D., Nugent, N., \& Paterson, W. E. (Eds.). (2017). The European Union in crisis. Basingstoke: Palgrave MacMillan.

Egeberg, M., \& Trondal, J. (2018). An organizational approach to public governance. Oxford: Oxford University Press.

Etzold, T. (2020). The Nordic council of ministers: Aspirations for more political relevance. Politics and Governance, 8(4), 11-20.

Falkner, G. (Ed.). (2016). The EU's current crisis and its policy effects: Research design and comparative findings. Journal of European Integration, 38(3), 219-235.

Forsberg, T. (2013). The rise of Nordic defence cooperation: A return to regionalism? International Affairs, 89(5), 1161-1181.

Fukuyama, F. (2016). Macro theory and the study of political development. Scandinavian Political Studies, 39(3), 207-225.

Genschel, P., \& Jachtenfuchs, M. (2018). From market integration to core state powers: The Eurozone crisis, the refugee crisis and integration theory. Journal of Common Market Studies, 56(1), 178-196.

Götz, N., \& Haggrén, H. (Eds.). (2009). Regional cooperation and international organisations: The Nordic model in transnational alignment. London: Routledge.

Graziano, P., \& Halpern, C. (2016). EU governance in times of crisis: Inclusiveness and effectiveness beyond the 'hard' and 'soft' law divide. Comparative European Politics, 14(1), 1-19.

Haugevik, K., \& Sending, O. J. (2020). The Nordic balance revisited: Differentiation and the foreign policy repertoires of the Nordic states. Politics and Governance, 8(4), 110-119.

Hooghe, L., \& Marks, G. (2009). A postfunctionalist theory of European integration: From permissive consensus to constraining dissensus. British Journal of Political Science, 39, 1-23.

Hooghe, L., \& Marks, G. (2019). Grand theories of European integration in the twenty-first century. Journal of European Public Policy, 26(8), 1113-1133.

Hyde-Price, A. (2018). Epilogue: 'Nordicness': Theory and practice. Global Affairs, 4(4/5), 435-443.

Isaksen, H. (2012). Finanstilsynet-utenfor og innenfor: En studie av Finanstilsynets arbeid med EU-regelverk [The financial supervisory authority of Norwayoutside and inside: A study of the agency's EU regulatory governance] (Unpublished Master dissertation). University of Oslo, Oslo, Norway.

Jacobsson, B., Lægreid, P., \& Pedersen, O. K. (2004). Europeanization and transnational states. London: Routledge.

Jones, B. D., \& Baumgartner, F. R. (2005). The politics of attention: How government prioritizes problems. Chicago, IL: University of Chicago Press. 
Jones, E. (2018). Towards a theory of disintegration. Journal of European Public Policy, 25(3), 440-451.

Kettunen, P., Lundberg, U., Österberg, M., \& Petersen, K. (2016). The Nordic model and the rise and fall Nordic cooperation. In J. Strang (Ed.), Nordic cooperation: A European region in transition (pp. 69-92). London and New York, NY: Routledge.

Kilpeläinen, S. (2020). Developing Nordic cooperation in renewable electricity policy: Exploring views from Finland and Sweden. Politics and Governance, 8(4), 44-52.

Kingdon, J. (1984). Agendas, alternatives and public policies. Boston, MA: Little Brown.

Kjøndal, K. (2020). Nordic cooperation in the nuclear safety sector: High, low, or differentiated integration? Politics and Governance, 8(4), 33-43.

Knutsen, O. (Ed.). (2017). The Nordic models in political science. Bergen: Fagbokforlaget.

Lægreid, P., \& Rykkja, L. H. (2020). Nordic administrative collaboration: Scope, predictors and effects on policy design and administrative reform measures. Politics and Governance, 8(4), 21-32.

Leruth, B., Gänzle, S., \& Trondal, J. (2019). Differentiated integration and disintegration in the European Union after Brexit: Risks versus opportunities. Journal of Common Market Studies, 57(6), 1383-1394.

Leruth, B., Trondal, J., \& Gänzle, S. (2020). Party positions on differentiated European integration in the Nordic countries: Growing together, growing apart? Politics and Governance, 8(4), 89-99.

Lodge, M., \& Wegrich, K. (Eds.). (2012). Executive politics in times of crisis: Executive politics and governance. Basingstoke: Palgrave Macmillan.

March, J. G. (1999). A learning perspective on the network dynamics of institutional integration. In M. Egeberg \& P. Lægreid (Eds.), Organizing political institutions (pp. 129-158). Oslo: Scandinavian University Press.

March, J. G., \& Olsen, J. P. (1989). Rediscovering institutions. New York, NY: The Free Press.

March, J. G., \& Olsen, J. P. (1998). The institutional dynamics of international political orders. International Organization, 52(4), 943-969.

Mény, Y. (2014). Managing the EU Crises: Another way of integration by stealth. West European Politics, 37(6), 1336-1353.

Miljan, T. (1977). The reluctant Europeans: The attitudes of the Nordic countries towards European integration. Montréal: McGill-Queen's University Press.

Olesen, T. B., \& Strang, J. (2016). European challenge to Nordic institutional cooperation: Past, present, future. In J. Strang (Ed.), Nordic Cooperation (pp. 27-47). London: Routledge.

Olsen, A. L. (2016). Nordiske forvaltningsnettverk $i$ en EU-kontekst: En casestudie av nettverksdeltakelsen til Direktoratet for samfunnssikkerhet og beredskap [Nordic administrative networks in an EU context: A case study of networking by the Norwegian Direc- torate for Civil Protection] (Unpublished Master dissertation). University of Oslo, Oslo, Norway.

Olsen, J. P. (2007). Europe in search of political order. Oxford: Oxford University Press.

Olsen, J. P. (2016). Democratic accountability and the terms of political order. European Political Science Review, 9(4), 519-537.

Olsen, J. P., \& Sverdrup, B. O. (Eds.). (1998). Europa i Norden [Europe in Norden]. Oslo: Tano Aschehoug.

Pierson, P. (2000). The limits of design: Explaining institutional origins and change. Governance, 13(4), 475-499.

Pierson, P. (2004). Politics in time. Princeton, NJ: Princeton University Press.

Riddervold, M., Trondal, J., \& Newsome, A. (Eds.). (2020). The Palgrave handbook of EU crisis. Houndmills: Palgrave Macmillan.

Schimmelfennig, F., \& Winzen, T. (2019). Grand theories, differentiated integration. Journal of European Public Policy, 26(8), 1172-1192.

Schrama, R., Martinsen, D. S., \& Mastenbroek, E. (2020). Going Nordic in European administrative networks? Politics and Governance, 8(4), 65-77.

Schulz, D. F., \& Henökl, T. (2020). New alliances in post-Brexit Europe: Does the new Hanseatic League revive Nordic political cooperation? Politics and Governance, 8(4), 78-88.

Skowronek, S. (1982). Building a new American state. Cambridge: Cambridge University Press.

Søetorp, Ø. (2012). Påvirkning gjennom medvirkning? En studie av Helsedirektoratets arbeid med EUs politikk [Influence through participation? A study of EU-related politics in the Norwegian Health Directorate] (Unpublished Master dissertation). University of Oslo, Oslo, Norway.

Stegmann McCallion, M., \& Brianson, A. (Eds.). (2018). Nordic states and European integration: Awkward partners in 419 the North? Basingstoke: Palgrave MacMillan.

Strang, J. (Ed.). (2016). Nordic cooperation: A European region in transition. London and New York, NY: Routledge.

Sundelius, B., \& Wiklund, C. (1979). The Nordic community: The ugly duckling of regional cooperation. Journal of Common Market Studies, 18(1), 59-69.

Teigen, D. O., \& Trondal, J. (2015). Fler-nivåadministrasjon på statistikkområdet [Multilevel administration in the field of statistics]. Nordisk Administrativt Tidsskrift, 92(3), 24-41.

Time, M. S., \& Veggeland, F. (2020). Adapting to a global health challenge: Managing antimicrobial resistance in the Nordics. Politics and Governance, 8(4), 53-64.

Trondal, J. (2020). Public administration and the study of political order: Towards a framework for analysis. Politics and Governance, 8(4), 120-130.

Trondal, J., \& Bauer, M. W. (2017). Conceptualizing the European multilevel administrative order: Capturing variation in the European administrative system. 
European Political Science Review, 9(1), 73-94.

Turner, B., \& Nordquist, G. (1982). The other European community: Integration and cooperation in Northern Europe. Houndmills: Palgrave Macmillan.

Vestlund, N. M. (2015). Pooling administrative resources through EU regulatory networks. Journal of European Public Policy, 24(1), 1-20.

Vollaard, H. (2014). Explaining European disintegration. Journal of Common Market Studies, 52(5), 1142-1159.

Vollaard, H. (2018). European disintegration. Bas- ingstoke: Palgrave Macmillan.

Wæver, O. (1992). Nordic nostalgia: Northern Europe after the Cold War. International Affairs, 68(1), 77-102.

Webber, D. (2019). Trends in European political (dis)integration: An analysis of postfunctionalist and other explanations. Journal of European Public Policy, 26(8), 1134-1152.

Wiener, A., Börzel, T., \& Risse, T. (Eds.). (2019). European integration theory. Oxford: Oxford University Press.

\section{About the Authors}

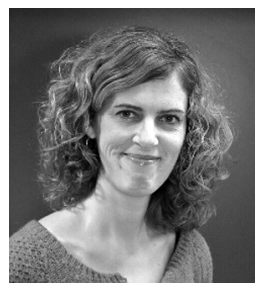

Anne Elizabeth Stie is Associate Professor at University of Agder, Norway. She has previously worked at ARENA Centre for European Studies, University of Oslo. Her main research interests are related to questions about the preconditions for democracy beyond the nation-state, European integration, the institutions and decision-making processes of the European Union and accountability.

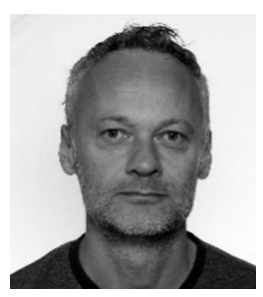

Jarle Trondal is Professor of Political Science at the University of Agder and at the University of Oslo, ARENA Centre for European Studies. His main fields of research are public policy and administration, European integration, organisational studies, decision-making and international organisations. 